\title{
A Bacterium with Echinuliform (Nonprosthecate) Appendages
}

\author{
J. B. McGREGOR-SHAW, K. B. EASTERBROOK, and R. P. McBRIDE
}

Departments of Biology and Microbiology, Dalhousie University, Halifax, Nova Scotia, Canada

A bacterium with the general properties of a member of the family Pseudomonadaceae has been isolated from infusions of decaying marine algae (Nova Scotia). The organism possesses rigid, randomly arranged appendages that are nonprosthecate and can best be described as "echinuliform" (spinelike).

During a survey of bacterial populations in infusions of decaying marine algae (Fink Cove, Nova Scotia), 60 organisms were isolated in pure culture. One of these possessed, in addition to a polar monotrichous flagellum, numerous straight spines (Fig. 1). After subculturing this organism for 3 months at $20 \mathrm{C}$ on ZoBell medium (7), it was observed that both the proportion of cells with spines and the number of spines per cell had greatly decreased when compared with the original isolate. In contrast, many more cells were flagellated. Subculturing such cultures at $35 \mathrm{C}$ resulted in the production of many spines by most cells, but these failed to produce flagella (Fig. 2).

The bacterium is gram-negative and in young cultures is a coccobacillus measuring 1 to 1.5 $\mu \mathrm{m}$ with rounded, somewhat pointed ends. In older cultures, long rods, as well as enlarged forms, are common. The organism occurs singly or, especially when spines are present, in clumps. When motile, a monotrichous polar flagellum is present with a wavelength of approximately $1.8 \mu \mathrm{m}$. The location of spines is unrestricted, and they measure about $70 \mathrm{~nm}$ in diameter and 1 to $3 \mu \mathrm{m}$ in length. Striations, present on the surface of the spines, are $12 \mathrm{~nm}$ apart. Usually, either spines or a flagellum are present, but both have rarely been observed on the same cell.

Colonies grown on ZoBell seawater agar for $48 \mathrm{~h}$ at $20 \mathrm{C}$ measure $2 \mathrm{~mm}$ in diameter and are umbonate, fimbriate, and unpigmented. Growth on slants is filiform with a slight erose edge. The bacterium is a facultative aerobe with an optimum growth temperature of $32 \mathrm{C}$. The organism will not grow in the absence of salt, and all media used for its cultivation are reconstituted in synthetic seawater containing $3 \%$ salt. Acid (as measured by pH change), but not gas, is produced from lactose, glucose, sucrose, galactose, mannose, and arabinose. Urea is hydrolyzed, catalase and oxidase are produced, but gelatin is not liquefied. Indole, methyl red, Voges-Proskauer, and nitrate reduction tests are all negative. Acetic acid is not produced from $5 \%$ ethanol. The guanine plus cytosine content of the bacterial deoxyribonucleic acid, as determined by buoyant density measurement, is $57.7 \%$. These properties are typical of certain members of the family Pseudomonadaceae.

To date only three reports of bacteria with spines as described herein have been made. Leifson (3) isolated an organism from the DuPage river near Chicago, but he was unable to maintain it in the spined form in pure culture. Staley (6) observed an organism with similar appearance in fresh water from the Putah Creek overflow (Davis, Calif.) and described it as possessing type 5 appendages, but he did not culture it. Moll and Ahrens (4) isolated a bacterium, thought to be an Agrobacterium variant, from brackish water of the Elbe river and, by use of an electron microscope, demonstrated the structure of the spines. These last workers regarded the spines as a new type of fimbria.

The term fimbriae is usually restricted to nonflagellar, filamentous appendages that are smaller and generally more numerous than are flagella (1). The structures described here are very much larger than flagella, resembling more closely the spines observed on the spores of certain streptomycetes. It would seem preferable, and it is proposed here, to describe such appendages as "echinuliform" and cells possessing them as "echinulate."

The fine structure of these appendages is described in detail elsewhere (2), and it needs only to be stated here that, although they are attached to the cell surface, they are morpho- 


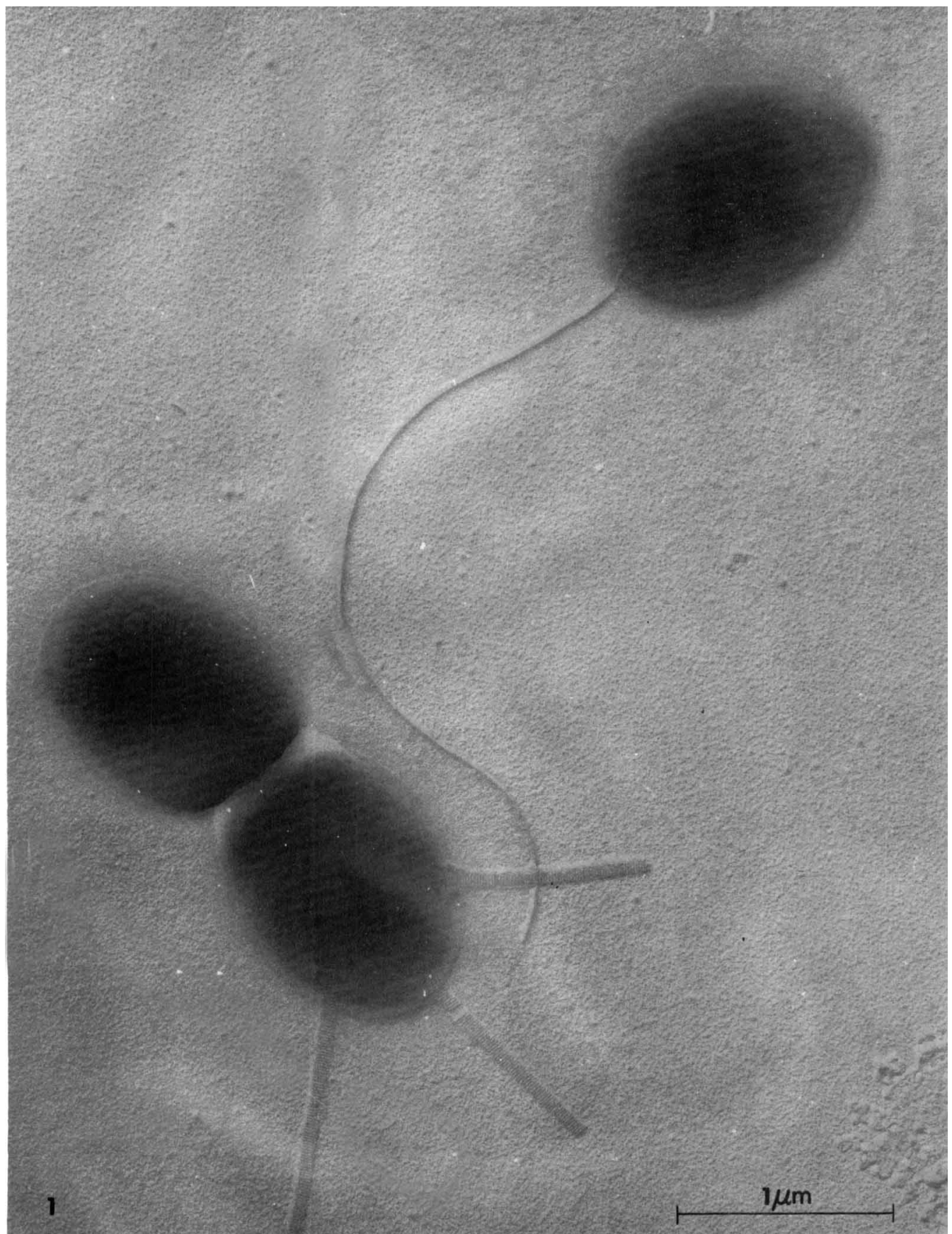

FIG. 1. Bacteria possessing either a polar flagellum or spines. Shadowed with platinum and palladium.

logically distinct entities rather than extensions of the cell wall. Appendages of this type are recognized as being nonprosthecate $(5,6)$, for they are not bounded by part of the cell wall (5). The finding of echinuliform appendages on bacteria from such widespread geographical locations indicates that they are not a unique structure, although presumably their occurrence is restricted to aquatic environments. The function of such structures can at present only 


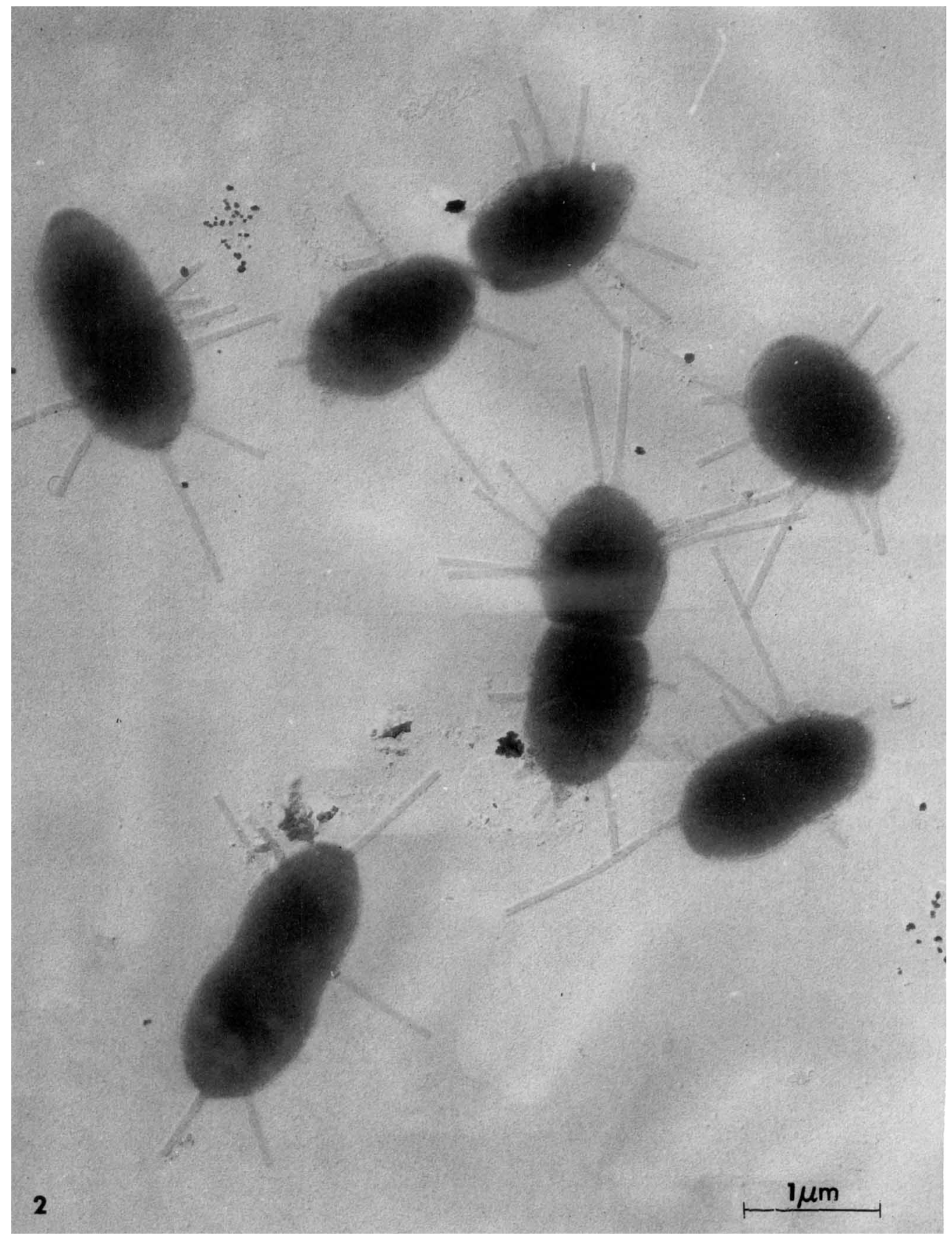

FIG. 2. Bacteria from a culture (35 C) which produced only spines. Shadowed with platinum and palladium. 
be conjectured, but the fact that organisms possessing them readily aggregate and settle in static culture suggests prima facie that they may be involved in colony formation under conditions which would normally favor dispersion.

The purification and chemical analysis of the spines is currently being undertaken to provide more information on the structure and formation of these unusual appendages.

We thank J. Macedo and C. Helleiner for preparing and characterizing the bacterial deoxyribonucleic acid.

The investigation was supported in part by grant A6687 to one of us (R. M.) from the National Research Council (Canada).

\section{REPRINT REQUESTS}

Address requests for reprints to: Prof. K. B. Easterbrook, Department of Microbiology, Faculty of
Medicine, Dalhousie University, Halifax, Nova Scotia, Canada.

\section{LITERATURE CITED}

1. Duguid, J. P. 1968. The function of bacterial fimbriae. Arch. Immunol. Ther. Exp. 16:173-188.

2. Easterbrook, K. B., McGregor-Shaw, J. B., and McBride, R. P. 1973. Ultrastructure of bacterial spines. Can. J. Microbiol., in press.

3. Leifson, E. 1960. Atlas of bacterial flagellation. Academic Press Inc., New York and London.

4. Moll, G., and R. Ahrens. 1970. Ein neuer Fimbrientyp. Arch. Mikrobiol. 70:361-368.

5. Schmidt, J. M. 1971. Prosthecate bacteria. Annu. Rev. Microbiol. 25:93-110.

6. Staley, J. T. 1968. Prosthecomicrobium and Ancalomicrobium: new prosthecate freshwater bacteria. J. Bacteriol. 95:1921-1942.

7. ZoBell, C. E. 1946. Marine microbiology. Chron. Bot. Waltham, Mass. 